\title{
THE ROLE OF SPECIAL EDUCATORS' EMOTIONAL INTELLIGENCE IN SELF-EFFICACY AND SOCIAL INCLUSION OF STUDENTS WITH DISABILITY
}

\author{
Konstantina Katsora ${ }^{i}$, \\ Stylianos Kaprinis, \\ Athanasios Strigas \\ Department of Sports Management, \\ Faculty of Human Movement and Quality of Life, \\ University of Peloponnese, \\ Greece
}

\begin{abstract}
:
The present study explores the correlation between the special educator's emotional literacy/ emotional intelligence and their self-efficacy regarding the empowerment and social inclusion of students with disability. The study examines a main sample of 114 special educators working in the Greek education system. The main research hypothesis is centered around the interrelationship between the two key notions while incorporating copious variables such as age, gender, education and teaching experience to thoroughly examine all aspects. The academic tools utilized within this research include the Schutte (1999) Self-Report Emotional Intelligence Test and the Teaching Students with Disabilities Efficacy Scale-TSDES (Dawson and Scott, 2013). The SPSS statistical package has been used to process the data regarding the descriptive and inductive statistical procedures that have been applied. In the end, it appears that emotional intelligence and the sense of self-efficacy of the special education teachers are inextricably linked as the increase in Emotional Intelligence also implies an increase in Self-Efficacy. In addition, with regard to the relations among the variables, it is noted that education is directly related to the level of Emotional Intelligence as $\mathrm{PhD}$ holders performed higher than holders of a Master's or Bachelor's degree. With regard to the participants' years of Experience, participants with 6-10 years of service had statistically significant superiority over other groups in terms of Emotional Intelligence. Overall, no statistically significant differences between the genders were found with the exception of the Professionalism and Instruction indicators in Self-Efficacy.
\end{abstract}

Keywords: educators' emotional intelligence, self-efficacy, special education

i Correspondence: email katsorak@gmail.com, skaprinis@uop.gr 


\section{Introduction}

In modern education systems, which are called to respond to the growth rates of societies, the school as an institution assumes the complex role of providing education beyond a rigid technocratic and strictly academic education. Thus, the teacher as the driving force of the institution serves as a facilitator of the unobstructed and beneficial coexistence of all members of the educational process by cultivating conditions of mutual respect and at the same time pursuing academic and other goals for all students. This complex role of the teacher requires a particular set of skills and competences. The sense of self-efficacy of the teacher becomes a key pillar of his or her project without being a self-evident or a direct result of solely, his/her/their academic studies but also sourced and inextricably linked to their emotional intelligence and education. (Brackett, Rivers, Shiffman Lerner, Salovey, 2006; Di Fabio \& Palazzeschi, 2008; Poulou, 2017; Sabina Valente, Veiga-Branco, Rebelo, Lourenço, Cristóvão, 2020). Emotional intelligence is a paramount skill for the successful fulfilment of the latter tasks by transforming schools into unique ecosystems that combine the learning experience with socialization and coexistence, where all participants are affected by the interactions and relationships that are developed (Roffey, 2008). This view is supported by other researchers (Groundwater-Smith, 2005; De Jong, 2005) who linked school structures to "living organisms" where factors such as emotional intelligence and the quality of interpersonal relationships are vital to their survival.

The importance of developing the emotional intelligence of all members of a school group is not limited strictly to student preparation and harmonious coexistence but also to the school's ability to provide an equal, safe and friendly learning environment for all participants. Moreover, the development of students' emotional education and skills is not only essential for their future success and well-being, but also for the school's ability to provide a safe equal and friendly space to learn and coexist (Gunter Caldarella, Korth, Young, 2012; Berkman, Glass, Brissette, Seeman, 2000). In addition, Mathews et al, (2006) show that in order for the school to provide an environment of "equality and social justice" development of students and teachers' emotional literacy is an essential element, since it will lay a solid foundation for constructive and genuine dialogue.

In this way, Mathews' understanding of emotional intelligence and education should become a high priority for education systems in conjunction with Raffey's Ecosystem Theoretical Analysis (2008), which emphasizes on dynamic symbioses and interactions between people within the school environment and the institution (school), rather than being competitive, composing a larger picture that emphasizes on the need for understanding, compassion and persuasion of equal and harmonious coexistence both in the school ecosystem and in a macro-level reflection, society.

The study regarding the correlation between the degree of development of emotional literacy and intelligence and self-efficacy is a topic of concern in modern literature. The additional parameter of the application of the above to educators working with students with disabilities is of increased interest as it will go hand in hand with the concepts of empowerment and social inclusion. It is, therefore, necessary to study in- 
depth at both theoretical/bibliographical and practical level in an attempt to create a solid academic reference base that will help modernize the school through the gradual removal from the view of emotional intelligence as secondary - in relation to academic qualifications - competence and its development to equal. The study, overall, tries to demonstrate the value of emotional intelligence and literacy as an essential capacity for well-being.

\section{Literature Review}

\subsection{The Concept of Emotional Intelligence}

According to Mayer and Salovey (1997) "emotional intelligence is the ability to perceive, evaluate and express emotions, the ability to approach and produce emotions that facilitate thought, the ability to understand and regulate emotions to promote emotional and cognitive growth." The researchers support the cognitive mental basis of emotional intelligence which concerns the cognitive processing of emotional information (Mayer, Carouso \& Salovey (1999; Mayer, Salovey \& Caruso, 2008). Essentially, they approach the concept as a set of abilities by emphasizing the interaction of cognitive and emotional abilities and specifically on the perception, understanding, organization and facilitation of emotions, highlighting how emotions help one's judgment. Essentially, they divide this in; (a) ability to perceive emotion, (b) ability to use emotion to facilitate thought, (c) ability to understand emotion, (d) ability to manage emotion.

In contrast, Bar-On $(1997 ; 2000 ; 2006)$ and Bar-On, Maree \& Elias (2007) argues that emotional intelligence is a series of non-cognitive abilities and focuses on the combination of personality traits, behavioral predispositions and abilities to adapt to the requirements of our environments. According to Bar-On (2000), a series of intrapersonal and interpersonal abilities of the individual's personality can facilitate for the management of the daily demands and difficulties of the environment, but also the changes that occur on a personal and social level. In this context, four categories of abilities are distinguished; (a) intrapersonal abilities which refer to self-management, emotional self-awareness, positive assertion, self-respect, self-realization, (b) interpersonal abilities, which include the management of our relationships with other people, social responsibility and empathy, (c) adaptability, which concerns the ability to adapt to changes, problemsolving skills, reality control and flexibility, (d) stress management that refers to stress tolerance and the control over the emotional pressure and the impulses/urges (Bar-On, 2000).

Goleman (1995; 1998; 2012) defines emotional intelligence as the ability of individuals to recognize their feelings (self-awareness), to regulate their emotions (selfregulation), to create self-motivation, to recognize the feelings of others (understanding others/ social awareness) which includes empathy and the management of the feelings of others (relationship management) and the ability to resolve conflicts (conflict resolution). Thus, Goleman refers to the interpretation of effectiveness based on the emotional, 
personal and social characteristics of the personality, giving personal and interpersonal skills of the individual paramount importance.

\subsection{The Concept of Self-Efficacy}

Bandura (1977) defined self-efficacy as the belief in the abilities of the individual themselves to organize and execute a course of actions procedures required to produce achievements. Therefore, self-efficacy refers to the beliefs that the individual has as to whether he will be able to cope with the demands of a particular role or to what extent he will successfully carry out a particular activity.

In the field of education, the information collected by individuals for the assessment of their abilities and, by extension, for the formation of their expectations of self-efficiency comes from (a) the teaching experience of the educators themselves and the achievements of their teaching career, (b) the teaching experience of their colleagues, where through the observation of the successes of their colleagues they strengthen their own confidence for what they can achieve themselves, (c) social and verbal means, when they receive positive feedback on their work, effectively positively affecting their attitude towards the completion of the goals they set and (d) psychological and emotional experiences when interpreting and evaluating their previous experiences, in a positive way, experience feelings of euphoric success and confidence in themselves and as a result, their perception of self-efficiency is strengthened (Bandura, 1997; TcchannemMoren et al, 2001).

According to Bandura (1997) individuals with low self-efficacy choose activities that perpetuate this negative state and, in a sense, obstruct their progress. On the opposite end, individuals with higher self-efficacy are more likely to partake in activities that will have a positive, constructive effect on their evolution. It also made clear that different experiences can also be formative of an individual's perception of efficacy and it is not an inherent personality trait rather that an acquired one formed through our experiences and with the potential to be altered. Interestingly, self-efficacy is also inextricably linked to the amount of effort that is to be put on the pursuit of a goal. Consequently, people who demonstrate higher self-efficacy are more possible to demonstrate higher persistence in their efforts and hence higher achievements as competency acquisition often requires stable effort and dedication. The sense of self-efficacy of educators is a topic echoed in a lot of research.

Klassen and Chiu (2010) explore how the notion of self-efficacy interacts and how it is affected by the educator's characteristics (gender, level of education and years of teaching experience). Their study measures self-efficacy regarding "instructional strategies, classroom management, and student engagement" their relation to stress/ feelings of anxiety that is caused by or heavily relevant to the job and the degree of satisfaction they demonstrate about their position. By looking at the result of their exploration we see that there is an absence of a linear connection between the domain of self-efficacy mentioned above and the educators' experience. On the contrary, numbers seemed to be fluctuating, with the mentioned factors demonstrating an upward tendency from the 
beginning to the middle of the career of the subjects and then decreasing. Gender was a factor of significant differentiation in the subject of stress. Male teachers scored lower on workload stress as well as in stress related to students' behavior in the classroom. While female teachers reported having more stress, they scored higher on self-efficacy regarding classroom management. Regarding the level of education, they were teaching in, teachers of elementary schools reported higher self-efficacy regarding classroom management and student engagement. Overall, educators that demonstrated higher levels of self-efficacy also had a more satisfactory working experience.

\subsection{Emotional Intelligence/Literacy and Teachers' Self-Efficacy}

Teachers' daily interactions with students, other teachers, administrators, parents, and the educational process itself creates high emotional demands (Brotheridge \& Grandey, 2002).

Research by Diamantopoulou, Gouridou \& Platsidou (2015) regarding the important emotional and social skills of teachers, as assessed by teachers, parents and students, include communication skills, self-control, empathy, conflict management skills, adaptability and cooperative disposition.

Platsidou and Mastrodimou (2009) argue that characteristics of effective teachers are adaptability, high impulse control, empathy and positive interpersonal relationships which are dimensions included in the concept of emotional intelligence.

The high positive correlation between emotional intelligence and teachers' selfefficacy is concluded in numerous studies (Ghanizadeh \& Moafian, 2010; Gürol, Özercan and Yalçın, 2010; Perry \& Ball, 2008; Rastegar \& Memarpour, 2009; Yin, Lee, Jin \& Zhang, 2013), which support the necessity of programs to improve teachers' emotional intelligence. In addition, researches (Corcoran \& Tormey, 2013; Penrose, Perry \& Bell, 2007) suggests that emotional intelligence is a predictor of teacher self-efficacy.

Chan (2004) studying the relationship between emotional intelligence and selfefficacy in secondary school teachers in Hong Kong found that teachers with high emotional intelligence report high self-efficacy, in contrast to teachers characterized by low emotional intelligence.

Similarly, Nikoopour, Farsani, Tajbakhsh and Kiyaie (2012), in a sample of 336 teachers, observed a significant positive correlation between emotional intelligence and self-efficacy. Furthermore, in terms of, demographic characteristics they found that educational experience has an effect on emotional intelligence and self-efficacy since teachers with more educational experience scored higher on both emotional intelligence and self-efficacy.

Poulou (2017) in her study attempts to affirm the connection between teachers' Emotional Intelligence and their ability to put to implementation Social and Emotional Learning in order to create and maintain quality relationships with their students and especially with students facing behavioral difficulties. In particular, she explores the relationship among perceived efficacy, emotional intelligence and the construction of relationships with their students. She found that teachers reporting higher on emotional 
intelligence would also build better interpersonal connections with their students and the building of relationships with students facing difficulties such as hyperactivity.

Similarly, Valente, Veiga-Branco, Rebelo, Lourenco and Cristóvão (2020) discuss the relationship between teachers' Emotional Intelligence Ability (EIA) and teachers' efficacy recognising teaching as heavy emotional labour that requires a variety of emotional regulation skills and abilities. Their study focuses on the way and degree EIA or, as described, in the quote "the ability to perceive, understand, express, classify, manage and regulate emotions", affects Teaching Efficacy. Their hypotheses are tested on a sample of 634 Portuguese teachers and their findings show a positive correlation between their EIAs and efficacy. Moreover, their study indicates that furthered teacher education was positively associated with higher EIAs. Contrastingly, in their findings, teachers with greater experience (in terms of length of serving) scored lower in EIAs could be explained an indication of burnout.

Additionally, in a sample of Italian teachers, Di Fabio and Palazzeschi (2008) explore EI with regard to self-efficacy. The main notions explored are interpersonal and intrapersonal skills and EI with male-identifying participants scoring higher in intrapersonal skills and female-identifying participants in interpersonal. Although they correlate perceived self-efficacy to intrapersonal skills, they underline the need for further research.

Chan (2008) in a sample of teachers based in Hong Kong also examines the influence of emotional intelligence in their perceived efficacy, placing however a higher focus on emotional regulation. On positive use and emotional assessment, teachers ranked particularly high, followed by empathic sensitivity and positive regulation. Positive regulation emerged as the positive determinant in predicting general selfefficacy using the four elements of perceived emotional intelligence as indicators of selfefficacy perceptions, while empathic sensitivity arose as the positive determinant in estimating self-efficacy to benefit others. Chan (2008) had also associated the teachers' emotional intelligence with their efficacy towards stress coping. Chan observed that intrapersonal and interpersonal emotional intelligence reflect highly successful stress coping mechanisms.

Emotional literacy in teaching is deemed as indispensable by EminoğluKüçüktepe, Akbağ and Eminoğlu-Ozmercan (2017) that have also a published study on the correlation between the levels of Emotional Literacy (EL) and the teachers' selfefficacy. They examined a sample of 318 people (pre-service teachers). An interesting result in their study was that of gender result differentiation, where female-identifying participants demonstrated significantly higher scores in both social competence and emotional literacy subscales. 


\section{Material and Methods}

\subsection{Sample}

This survey involved special education teachers $(\mathrm{N}=114)$ including women $(\mathrm{n}=88)$ and men $(n=26)$ Regarding the level of education of the participants, 38 people $(33.3 \%)$ have obtained a Bachelor's degree, while 69 people $(60.5 \%)$ had a master's degree. Finally, 7 teachers $(6.1 \%)$ had a PhD. Regarding the experience of the participants in the special education, 60 teachers had up to 5 years of experience $(\mathrm{N}=60)$ making $52.6 \%$ hence becoming the vast majority, $15(\mathrm{~N}=15)$ teachers had the experience of 6 to 10 years making $13.2 \%$, while $24(\mathrm{~N}=24)$ people had experience ranging from 11 to 20 years. Moreover, 15 participants $(\mathrm{N}=15)$ or $13.2 \%$ had experience in special education over 21 years. Regarding the age of the participants of the research out of the total of the sample $(\mathrm{N}=114)$, there is a division into four main categories; $22-30$ with forty participants $(\mathrm{N}=40)$ making the $35.1 \%$, while being the most populous category, 31-40 with twenty-two participants $(\mathrm{N}=22)$ and $19.3 \%, 41-50$ with 21 participants $(\mathrm{N}=21)$ making $18.4 \%$ and $51+$ with thirty-one participants $(\mathrm{N}=31)$ and $27.2 \%$.

\subsection{Research Tools}

For the purposes of the research, teachers were given two questionnaires: (a) the Schutte Self-Report Emotional Intelligence Test - SSEIT, (b) the Teaching Students with Disabilities Efficacy Scale - TSDES of Dawson and Scott (2013). The SSEIT questionnaire was used to measure the emotional intelligence of special education teachers and includes 33 questions structured into four (4) subscale-factors: (a) Emotion Perception, which assesses a person's ability to perceive emotions, (b) Utilizing Emotion, which assesses the ability to exploit emotions, (c) Managing Self Related Emotion which assesses the ability to manage personal emotions and (d) Managing Other's Emotion that assesses the ability to manage emotions of other people. The TSDES questionnaire was used to measure the self-efficacy of special education teachers. The questionnaire incorporates five (5) subcategories - factors: (a) Instruction, (b) Professionalism, (c) Teacher Support, (d) Classroom Management and (e) Related Duties.

\subsection{Data Collection}

Data was collected exclusively in an electronic form by utilizing Google Forms, an electronic software that can ensure the preservation of the users' anonymity by restricting access to anything other than the predetermined information and at the same time is relatively easy to use and friendly to the average user. The electronic questionnaire was distributed via social media on pages regarding special education as well as an e-mail distribution to many special schools.

\subsection{Statistical Analysis}

The SPSS statistical package was used to process the data. Descriptive and inductive statistical procedures have been applied. For the analysis of categorical variables, the 
absolute and relative frequency distribution of responses has been calculated, while for quantitative variables there has been a calculation of the means and standard deviation. For the main hypothesis of the research, concerning the correlation of the Emotional Intelligence of special education teachers and their Self-Efficacy, towards the inclusion and social integration of students with disabilities, a Pearson correlation check has been conducted. To confirm the correlation in the Regression Analysis a Spearman's rho analysis was utilised as well. T-test and ANOVA variance analyses were carried out to check the remaining statistical cases. In the case of a significant deviation in the factor, in the ANOVA analyses, there have been post hoc analyses conducted utilising Tukey's Test aiming to determine the subgroup(s) that create the statistically important deviation. The significance level is set to $\mathrm{p}<.05$ and at $\mathrm{p}<.01$ in the Regression Analysis.

Simple descriptive analysis techniques (Means, Standard Deviation, Frequency, etc.) were used to analyze the data and extract the results. In addition, in the Emotional Intelligence and Self-Efficiency questionnaires were applied [1] the t-test analysis for independent groups and [2] the Analysis of Variation (ANOVA) to check the significance of the difference in the averages of the groups. Also, Levene's test for Equality of Variation was used to identify the groups causing the most significant differences. The significance level is set to $\mathrm{p}<.05$. In the correlation of EI and SE a Regression Analysis (a Spearman's rho) was conducted.

\section{Results}

\section{a. Emotional Intelligence and Years of Experience}

One of the factors that affected the EI of the participants was the years of experience in the field of education. A one-way between subjects ANOVA was conducted to compare the effect of the Experience of the candidates $(0-5,6-10,11-20,21+)$ and their degree of Emotional Intelligence. There was a significant effect of the group the candidates belong to at the $\mathrm{p}<.05$ scale at the conditions $(\mathrm{F}=3,110=2,703)$ (Table 1$)$.

Table 1: Emotional Intelligence $X$ Experience

\begin{tabular}{|l|l|l|c|c|c|c|}
\hline & & $\begin{array}{c}\text { Sum of } \\
\text { Squares }\end{array}$ & df & $\begin{array}{c}\text { Mean } \\
\text { Square }\end{array}$ & F & Sig. \\
\hline \multirow{2}{*}{$\begin{array}{l}\text { Emotional Intelligence } \\
x \text { Experience }\end{array}$} & Between Groups & 991,591 & 3 & 330,530 & \multirow{2}{*}{2,703} & \multirow{2}{*}{, 049} \\
\cline { 2 - 6 } & Within Groups & 13451,400 & 110 & 122,285 & & \\
\cline { 2 - 6 } & Total & 14442,991 & 113 & & & \\
\hline
\end{tabular}

Post Hoc comparisons using the Tukey HSD test indicated that comparing educators that had 0-5 years of experience in comparison to 6-10 years of experience had a statistically significant difference on the $p<.05$ scale $(p=.035)$ with the latter category scoring significantly higher (Table 2). 
Table 2: Tukey HSD X Experience

\begin{tabular}{|c|c|c|c|c|c|c|}
\hline \multicolumn{7}{|c|}{ Multiple Comparisons } \\
\hline \multicolumn{7}{|c|}{ Dependent Variable: Emotional Intelligence } \\
\hline \multicolumn{7}{|c|}{ Tukey HSD } \\
\hline \multirow{2}{*}{$\begin{array}{c}\text { (I) } \\
\text { Experience_New }\end{array}$} & \multirow{2}{*}{$\begin{array}{c}(\mathrm{J}) \\
\text { Experience_New }\end{array}$} & \multirow{2}{*}{$\begin{array}{c}\text { Mean } \\
\text { Difference } \\
\text { (I-J) }\end{array}$} & \multirow[b]{2}{*}{$\begin{array}{l}\text { Std. } \\
\text { Error }\end{array}$} & \multirow[b]{2}{*}{ Sig. } & \multicolumn{2}{|c|}{ 95\% Confidence Interval } \\
\hline & & & & & $\begin{array}{l}\text { Lower } \\
\text { Bound }\end{array}$ & $\begin{array}{l}\text { Upper } \\
\text { Bound }\end{array}$ \\
\hline \multirow[t]{3}{*}{$0-5$} & $11-20$ & -.233 & 2.671 & 1.000 & -7.20 & 6.73 \\
\hline & $21+$ & -2.833 & 3.192 & .811 & -11.16 & 5.49 \\
\hline & 6-10 & $-8.767^{*}$ & 3.192 & .035 & -17.09 & -.44 \\
\hline \multirow[t]{3}{*}{$11-20$} & $0-5$ & .233 & 2.671 & 1.000 & -6.73 & 7.20 \\
\hline & $21+$ & -2.600 & 3.640 & .891 & -12.10 & 6.90 \\
\hline & 6-10 & -8.533 & 3.640 & .094 & -18.03 & .96 \\
\hline \multirow[t]{3}{*}{$21+$} & $0-5$ & 2.833 & 3.192 & .811 & -5.49 & 11.16 \\
\hline & $11-20$ & 2.600 & 3.640 & .891 & -6.90 & 12.10 \\
\hline & $6-10$ & -5.933 & 4.038 & .459 & -16.47 & 4.60 \\
\hline \multirow[t]{3}{*}{$6-10$} & $0-5$ & $8.767^{*}$ & 3.192 & .035 & .44 & 17.09 \\
\hline & $11-20$ & 8.533 & 3.640 & .094 & -.96 & 18.03 \\
\hline & $21+$ & 5.933 & 4.038 & .459 & -4.60 & 16.47 \\
\hline
\end{tabular}

To complement the foresaid results a Bayesian ANOVA was conducted. On the table, we can observe that indeed educators that 6-10 years of experience demonstrate a higher Mean ( $M=139.867)$ while educators that fall under the rest of the categories demonstrate similar Means on an estimation of 132.000. ( $\mathrm{M}=131.100, \mathrm{M}=131.333, \mathrm{M}=133.933)$ (Table 3).

Table 3: Bayesian ANOVA. Estimates of Coefficients Experience X Emotional Intelligence (EI)

\begin{tabular}{|c|c|c|c|c|c|}
\hline \multicolumn{6}{|c|}{ Bayesian Estimates of Coefficients $\mathrm{a}, \mathrm{b}, \mathrm{c}$} \\
\hline \multirow{2}{*}{ Parameter } & \multicolumn{3}{|c|}{ Posterior } & \multicolumn{2}{|c|}{ 95\% Credible Interval } \\
\hline & Mode & Mean & Variance & Lower Bound & Upper Bound \\
\hline Experience $\_=0-5$ & 131.100 & 131.100 & 2.076 & 128.271 & 133.929 \\
\hline Experience_=6-10 & 139.867 & 139.867 & 8.303 & 134.208 & 145.525 \\
\hline Experience_ $=11-20$ & 131.333 & 131.333 & 5.190 & 126.860 & 135.807 \\
\hline Experience $\_=21+$ & 133.933 & 133.933 & 8.303 & 128.275 & 139.592 \\
\hline \multicolumn{6}{|c|}{ a. Dependent Variable: Emotional Intelligence } \\
\hline \multicolumn{6}{|c|}{ b. Model: Experience_New } \\
\hline \multicolumn{6}{|c|}{ c. Assume standard reference priors. } \\
\hline
\end{tabular}

\section{b. Emotional Intelligence and Level of Education}

A one-way between subjects ANOVA was conducted to compare the effect of the level of formal Education held by the candidates (Bachelor's, Master's, and Doctorate) and their EI. There was a significant effect of the level of formal Education held on the Emotional Intelligence of the special educators at the $\mathrm{p}<.05$ of the conditions $(\mathrm{F}=2,111=$ 3,328), $\mathrm{p}=.039$ (Table 4 ). 
Konstantina Katsora, Stylianos Kaprinis, Athanasios Strigas

THE ROLE OF SPECIAL EDUCATORS' EMOTIONAL INTELLIGENCE IN

SELF-EFFICACY AND SOCIAL INCLUSION OF STUDENTS WITH DISABILITY

Table 4: ANOVA Emotional Intelligence X Education

\begin{tabular}{|l|c|c|c|c|c|}
\hline ANOVA \\
\cline { 1 - 4 } Emotional Intelligence $x$ Education \\
\cline { 1 - 4 } & Sum of Squares & df & Mean Square & F & Sig. \\
\hline Between Groups & 817,160 & 2 & 408,580 & \multirow{2}{*}{, 039} \\
\hline Within Groups & 13625,831 & 111 & 122,755 & & \\
\hline Total & 14442,991 & 113 & & & \\
\hline
\end{tabular}

Post Hoc comparisons using the Tukey HSD test indicated that comparing educators that had a Bachelor's degree to their possession and educators that had obtained a Doctorate had a statistically significant difference on the $p<.05$ scale $(p=.042)$ with the latter category scoring significantly higher. Moreover, comparing special educators that have completed their doctoral studies to the special educators that have obtained a Master's degree suggested a statistically significant difference on the $p<.05$ scale $(p=.034)$ that the ones with a doctorate degree scored again higher (Table 5).

Table 5: Tukey HSD Emotional Intelligence X Education

\begin{tabular}{|c|c|c|c|c|c|c|}
\hline \multicolumn{7}{|c|}{ Multiple Comparisons } \\
\hline \multicolumn{7}{|c|}{ Dependent Variable: Emotional Intelligence } \\
\hline \multicolumn{7}{|c|}{ Tukey HSD } \\
\hline \multirow{2}{*}{$\begin{array}{c}\text { (I) } \\
\text { Education_New }\end{array}$} & \multirow{2}{*}{$\begin{array}{c}(\mathrm{J}) \\
\text { Education_New }\end{array}$} & \multirow{2}{*}{$\begin{array}{c}\text { Mean } \\
\text { Difference } \\
\text { (I-J) }\end{array}$} & \multirow{2}{*}{$\begin{array}{l}\text { Std. } \\
\text { Error }\end{array}$} & \multirow[b]{2}{*}{ Sig. } & \multicolumn{2}{|c|}{ 95\% Confidence Interval } \\
\hline & & & & & $\begin{array}{l}\text { Lower } \\
\text { Bound }\end{array}$ & $\begin{array}{l}\text { Upper } \\
\text { Bound }\end{array}$ \\
\hline \multirow[t]{2}{*}{ Bachelor's } & Doctorate & $-11.169^{*}$ & 4.557 & .042 & -21.99 & -.34 \\
\hline & Master's & -.026 & 2.238 & 1.000 & -5.34 & 5.29 \\
\hline \multirow[t]{2}{*}{ Doctorate } & Bachelor's & $11.169^{*}$ & 4.557 & .042 & .34 & 21.99 \\
\hline & Master's & $11.143^{*}$ & 4.395 & .034 & .70 & 21.58 \\
\hline \multirow[t]{2}{*}{ Master's } & Bachelor's & .026 & 2.238 & 1.000 & -5.29 & 5.34 \\
\hline & Doctorate & $-11.143^{*}$ & 4.395 & .034 & -21.58 & -.70 \\
\hline
\end{tabular}

To complement the foresaid results a Bayesian ANOVA was conducted. On the table, we can observe that indeed educators that have to finish their doctoral studies demonstrate a higher Mean $(\mathrm{M}=143.143)$ while educators that have only completed their Bachelors' and Masters' demonstrate similar Means on an estimation of 132.000. $(\mathrm{M}=132.974, \mathrm{M}=$ 132.000) (Table 6). 
Konstantina Katsora, Stylianos Kaprinis, Athanasios Strigas

THE ROLE OF SPECIAL EDUCATORS' EMOTIONAL INTELLIGENCE IN

SELF-EFFICACY AND SOCIAL INCLUSION OF STUDENTS WITH DISABILITY

Table 6: Bayesian ANOVA Estimates Emotional Intelligence X Education

\begin{tabular}{|l|c|c|c|c|c|}
\hline Bayesian Estimates of Coefficients $\mathbf{a}, \mathbf{b}, \mathbf{c}$ \\
\cline { 2 - 6 } Parameter & Mode & Mean & Variance & Lower Bound & Upper Bound \\
\hline Education = Bachelor's & 131.974 & 131.974 & 3.290 & 128.412 & 135.535 \\
\hline Education = Doctorate & 143.143 & 143.143 & 17.858 & 134.845 & 151.441 \\
\hline Education = Master's & 132.000 & 132.000 & 1.812 & 129.357 & 134.643 \\
\hline a. Dependent Variable: Emotional Intelligence \\
\hline b. Model: Education \\
\hline \multicolumn{7}{|l}{ c. Assume standard reference priors. }
\end{tabular}

\section{c. Self-Efficacy}

Regarding the statistical results on attitudes on the SE of the educators under the examined variable of Gender, there has been a t-test analysis for independent groups. It is noteworthy to mention that SE was calculated separately for each index (Instruction, Professionalism, Teacher Support, Classroom Management and Related Duties).

The female participants $(\mathrm{N}=89, \mathrm{M}=22.674157, \mathrm{SD}=2.043700)$ compared to the male participants $(\mathrm{N}=26, \mathrm{M}=21.4231, \mathrm{SD}=2.04370)$ under the index of Professionalism. Regarding that significance is set at $\mathrm{p}<0.05$ and the results demonstrate $\mathrm{p}=472$ and therefore we can assume that the variances are equal. We also observe that there is a statistically important difference $(p=.007)$ regarding Professionalism in SE between Male and Female participants with the latter scoring significantly higher (Table 7).

The female participants $(\mathrm{N}=89, \mathrm{M}=13.8539, \mathrm{SD}=1.36140)$ compared to the male participants $(\mathrm{N}=26, \mathrm{M}=13.1923, \mathrm{SD}=1.16685)$ under the index of Teacher Support. Regarding that significance is set at $p<0.05$ and the results demonstrate $p=.338$ and therefore we can assume that the variances are equal. We also observe that there is a statistically important difference $(p=.027)$ regarding Teacher Support in SE between Male and Female participants with the latter scoring significantly higher (Table 8).

\section{d. Correlating Self-Efficacy and Emotional Intelligence}

In order to test the main hypothesis of the article that "There will be statistically significant variances in the correlation between the Emotional Intelligence of special education teachers and their self-efficiency in the social inclusion of students with disability" a Spearman's rho correlation was conducted and the significant rate was set at the 0.01 level aiming to maximize accuracy. 
Konstantina Katsora, Stylianos Kaprinis, Athanasios Strigas

THE ROLE OF SPECIAL EDUCATORS' EMOTIONAL INTELLIGENCE IN

SELF-EFFICACY AND SOCIAL INCLUSION OF STUDENTS WITH DISABILITY

Table 7: T-Test $X$ Professionalism and Self-Efficacy

\begin{tabular}{|c|c|c|c|c|c|c|c|c|c|c|}
\hline \multicolumn{11}{|c|}{ Independent Samples Test } \\
\hline & & \multicolumn{2}{|c|}{$\begin{array}{c}\text { Levene's Test for } \\
\text { Equality of Variances }\end{array}$} & \multicolumn{7}{|c|}{ t-test for Equality of Means } \\
\hline & & \multirow[t]{2}{*}{$\mathbf{F}$} & \multirow[t]{2}{*}{ Sig. } & \multirow[t]{2}{*}{$\mathbf{t}$} & \multirow[t]{2}{*}{ df } & \multirow[t]{2}{*}{$\begin{array}{l}\text { Sig. (2- } \\
\text { tailed) }\end{array}$} & \multirow[t]{2}{*}{$\begin{array}{c}\text { Mean } \\
\text { Difference }\end{array}$} & \multirow[t]{2}{*}{$\begin{array}{l}\text { Std. Error } \\
\text { Difference }\end{array}$} & \multicolumn{2}{|c|}{$\begin{array}{c}95 \% \text { Confidence Interval } \\
\text { of the Difference }\end{array}$} \\
\hline & & & & & & & & & Lower & Upper \\
\hline \multirow[t]{2}{*}{ Professionalism } & $\begin{array}{l}\text { Equal variances } \\
\text { assumed }\end{array}$ & .520 & .472 & -2.770 & 113 & .007 & -1.25108 & .45169 & -2.14596 & -.35620 \\
\hline & $\begin{array}{l}\text { Equal variances } \\
\text { not assumed }\end{array}$ & & & -2.832 & 42.137 & .007 & -1.25108 & .44176 & -2.14251 & -.35965 \\
\hline
\end{tabular}

Table 8: T-Test X Teacher Support in Self-Efficacy

\begin{tabular}{|c|c|c|c|c|c|c|c|c|c|c|}
\hline \multicolumn{11}{|c|}{ Independent Samples Test } \\
\hline & & \multirow[t]{2}{*}{$F$} & \multirow[t]{2}{*}{ Sig. } & \multirow[t]{2}{*}{$t$} & \multirow[t]{2}{*}{ df } & \multirow[t]{2}{*}{$\begin{array}{l}\text { Sig. (2- } \\
\text { tailed) }\end{array}$} & \multirow[t]{2}{*}{$\begin{array}{c}\text { Mean } \\
\text { Difference }\end{array}$} & \multirow[t]{2}{*}{$\begin{array}{l}\text { Std. Error } \\
\text { Difference }\end{array}$} & \multicolumn{2}{|c|}{$\begin{array}{c}95 \% \text { Confidence Interval } \\
\text { of the Difference }\end{array}$} \\
\hline & & & & & & & & & Lower & Upper \\
\hline \multirow[t]{2}{*}{$\begin{array}{l}\text { Teacher } \\
\text { Support }\end{array}$} & $\begin{array}{l}\text { Equal variances } \\
\text { assumed }\end{array}$ & .752 & .388 & -2.247 & 113 & .027 & -.66162 & .29445 & -1.24499 & -.07826 \\
\hline & $\begin{array}{l}\text { Equal variances } \\
\text { not assumed }\end{array}$ & & & -2.446 & 46.738 & .018 & -.66162 & .27054 & -1.20596 & -.11729 \\
\hline
\end{tabular}


In Spearman's rho correlation coefficient, we can observe a strong positive correlation (.546) between the educators' emotional intelligence and self-efficacy. This correlation is statistically important on the .01 scale since our $p$ value is $<.001(p<0.001)$ (Table 9).

Table 9: Spearman's rho Self-Efficacy X Emotional Intelligence (SE X EI)

\begin{tabular}{|c|c|c|c|c|}
\hline \multicolumn{5}{|l|}{ Correlations } \\
\hline & & & $\begin{array}{c}\text { Self- } \\
\text { Efficacy }\end{array}$ & $\begin{array}{l}\text { Emotional } \\
\text { Intelligence }\end{array}$ \\
\hline \multirow[t]{6}{*}{ Spearman's rho } & \multirow[t]{3}{*}{ Self-Efficacy } & Correlation Coefficient & 1,000 &, $546^{* *}$ \\
\hline & & Sig. (2-tailed) &. & ,000 \\
\hline & & $\mathrm{N}$ & 114 & 114 \\
\hline & \multirow{3}{*}{$\begin{array}{l}\text { Emotional } \\
\text { Intelligence }\end{array}$} & Correlation Coefficient &, $546^{* *}$ & 1,000 \\
\hline & & Sig. (2-tailed) &, 000 & . \\
\hline & & $\mathrm{N}$ & 114 & 114 \\
\hline
\end{tabular}

\section{e. Regression}

Results of the multiple linear regression indicated that there is a significant effect between EI and SE and in special educators regarding the empowerment and social inclusion of students with disability. The correlation between SE and EI is statistically important as the $\mathrm{p}$ value is less than .01. In particular, $\mathrm{p}<.001$ indicates that if the EI value is increased by 1 unit and the rest of the variables remain unchanged there will be a .338 increase in SE. at an $99 \%$ confidence (Table 10 ).

Table 10: Multiple Linear Regression Self-Efficacy X Emotional Intelligence (SE X EI)

\begin{tabular}{|c|c|c|c|c|c|c|c|c|}
\hline \multicolumn{9}{|c|}{ Coefficients $^{a}$} \\
\hline \multirow{2}{*}{\multicolumn{2}{|c|}{ Model }} & \multicolumn{2}{|c|}{$\begin{array}{l}\text { Unstandardized } \\
\text { Coefficients }\end{array}$} & \multirow{2}{*}{$\begin{array}{c}\begin{array}{c}\text { Standardized } \\
\text { Coefficients }\end{array} \\
\text { Beta }\end{array}$} & \multirow[t]{2}{*}{$\mathbf{t}$} & \multirow[t]{2}{*}{ Sig. } & \multicolumn{2}{|c|}{$\begin{array}{l}\text { 99.0\% Confidence } \\
\text { Interval for B }\end{array}$} \\
\hline & & B & Std. Error & & & & $\begin{array}{l}\text { Lower } \\
\text { Bound }\end{array}$ & $\begin{array}{l}\text { Upper } \\
\text { Bound }\end{array}$ \\
\hline \multirow[t]{2}{*}{1} & (Constant) & 34,063 & 7,339 & & 4,641 & ,000 & 14,831 & 53,295 \\
\hline & $\begin{array}{l}\text { Emotional } \\
\text { Intelligence }\end{array}$ & ,338 & ,055 & ,501 & 6,128 & ,000 & 193 & ,482 \\
\hline
\end{tabular}

a. Dependent Variable: Self-Efficacy

Overall, after an ANOVA was conducted to examine if the above model is statistically on the whole significant, it was confirmed as the $p$ value was <.001 (Table 11).

Table 11: ANOVA -Statistical Significance

\begin{tabular}{|c|c|c|c|c|c|c|}
\hline \multicolumn{7}{|c|}{ ANOVA $^{a}$} \\
\hline \multicolumn{2}{|c|}{ Model } & Sum of Squares & df & Mean Square & $\mathbf{F}$ & Sig. \\
\hline \multirow[t]{3}{*}{1} & Regression & 1647,812 & 1 & 1647,812 & \multirow{2}{*}{37,553} & \multirow{2}{*}{, $000^{\mathrm{b}}$} \\
\hline & Residual & 4914,469 & 112 & 43,879 & & \\
\hline & Total & 6562,281 & 113 & & & \\
\hline \multicolumn{7}{|c|}{ a. Dependent Variable: Self Efficacy } \\
\hline \multicolumn{7}{|c|}{ b. Predictors: (Constant), Emotional Intelligence } \\
\hline
\end{tabular}




\section{Discussion}

The present study explored the correlation between the special educator's emotional intelligence and their self-efficacy regarding the empowerment and social inclusion of students with disability. The study, overall, tries to demonstrate the value of emotional intelligence and literacy as an essential capacity for well-being.

The main hypothesis of the research has been confirmed with a demonstration of a strong positive correlation between the Emotional Intelligence and Self-Efficacy of special educators. Similarly, in a Chan (2008) survey of 273 student teachers and active teachers. Chan used active and passive coping strategies to look at how effective teachers seem to feel and how emotional intelligence is a part of their personality. As a result, teachers' emotional intelligence and effectiveness influence coping strategies, such as psychological reactions used to control the nature of a stressor or how they think about it. In the same vein, Rastegar and Memarpour (2009) argue that there is a positive important connection between emotional intelligence and teacher self-efficacy in a sample of 72 English language teachers in secondary education, using the Emotional Intelligence Scale (EIS) and the Teachers' Self-Efficacy Scale (TSES). Kocoglu (2011) used two self-reporting questionnaires, (a) the emotional intelligence questionnaire developed by Reuven Bar-On (1997), and (b) the scale of teacher effectiveness (TSES) developed by Tschannen-Moran and Woolfolk-Hoy, to investigate the possible link between emotional intelligence and self-efficacy belief of 90 Turkish students of English literature (2001) There is a strong positive association between emotional intelligence and teacher selfefficacy, which is highly important in the teaching process. Students with strong selfefficacy conviction and emotional intelligence skills are more likely to utilize more and more efficient teaching tactics during the teaching process than students with low selfefficacy conviction and emotional intelligence skills. For instance, studies demonstrate that instructors with higher emotional intelligence use more effective teaching tactics (Olweus, 2001). Gürol, Özercan, and Yalçın (2010) conducted a comparable survey on a sample of 248 students from a University of Turkey pedagogical department, with the goal of determining if there is a relationship between emotional intelligence and instructors' perception of efficacy. The findings revealed that emotional intelligence and self-efficacy had a strong positive association. Emotional intelligence is positively connected with self-efficacy, according to the researchers, which is advantageous for both student teachers and teachers since one has the capacity to improve and has a favorable influence on the other.

Regarding the matter of gender, no statistically important differences have been noted in the participants neither on Emotional Intelligence nor on Self-Efficacy. Likewise, Chan (2004) has found no significant correlation between the gender of the educators and their self-efficacy. According to the results of Rastegar and Memarpour's (2009) teacher gender survey, there is no substantial difference between men and women in terms of emotional intelligence and self-efficacy. The findings of their study appear to be in line with previous studies by Chan (2004) and Hopkins and Bilimoria (2008), but they 
contradict the findings of Harrod and Scheer (2005), which found significant differences between men and women in terms of emotional intelligence, with the data indicating increased rates of emotional intelligence in women. According to Gürol, Zercan, and Yalcin (2010), both male and female instructors can indeed feel equally effective in the classroom because no significant statistical disparities were observed in terms of gender (Gürol, Zercan, \& Yalcin, 2010).

In the present research the variable of Experience moderately affected the Emotional intelligence of the special educators while at the same time had no effect on their Self-Efficacy. This can be considered to run on the same wavelength as Chan's (2004) findings, where differences in self-efficacy and emotional intelligence were also discovered depending on relevant work experience, with active instructors demonstrating greater levels of emotional intelligence and self-efficacy than student teachers. However, Chan (2004) examined the differences in Emotional Intelligence and Self Efficacy between two groups (active teachers and student teachers) while this research focuses solely on active teachers and divides them in categories depending on their years of teaching experience. In contrast, Rastegar and Memarpour (2009) found that experience is irrelevant to both notions examined.

\section{Recommendations}

Overall, it would definitely be productive to have a larger future research that addressed a wider sample of participants and could also incorporate factors such as third-party reports in comparison to self-reports. Another recommendation for further research would be to incorporate personality traits and/or situations in the participants' social environment that can potentially affect the turnout of the data.

\section{Conclusion}

The present article explores the correlation between the special educator's emotional literacy/ emotional intelligence and their self-efficacy regarding the empowerment and social inclusion of students with disability. The main research hypothesis is centered around the interrelationship between the two key notions while incorporating copious variables such as age, gender, education and teaching experience to thoroughly examine all aspects. The study regarding the correlation between the degree of development of emotional literacy and intelligence and self-efficacy is a topic of concern in modern literature. The additional parameter of the application of the above to educators working with students with disabilities is of increased interest as it will go hand in hand with the concepts of empowerment and social inclusion. The study, overall, tries to demonstrate the value of emotional intelligence and literacy as an essential capacity for well-being. The main hypothesis of the research has been confirmed with a demonstration of a strong positive correlation between the Emotional Intelligence and Self-Efficacy of special educators. There is a strong positive association between emotional intelligence and 
teacher self-efficacy, which is highly important in the teaching process. Educators with strong self-efficacy conviction and emotional intelligence skills are more likely to utilize more and more efficient teaching tactics during the teaching process than educators with low self-efficacy conviction and emotional intelligence skills. Regarding the matter of gender, no statistically important differences have been noted in the participants neither on Emotional Intelligence nor on Self-Efficacy. In the present research, the variable of Experience moderately affected the Emotional intelligence of the special educators while at the same time had no effect on their Self-Efficacy.

\section{Conflicts of Interest Statement}

The authors declare that there are no conflicts of interest.

\section{About the Authors}

Konstantina Katsora, is a graduate of English Language and Literature and has completed her studies as a Master of Science in Sport Management and Organization of Sport Activities for People with Disabilities. Her research interests focus on the study of people with disabilities in sports, special education and linguistics.

Stylianos Kaprinis (PhD) is a specialized educational staff, at the University of Peloponnese, Faculty of Human Movement and Quality of Life, Department of Sports Management. His research interests include sport psychology, school physical education planning and teaching students with disabilities. Moreover, his research area includes the evaluation of interventions in adapted physical activity and Sport Pedagogy.

Athanasios Strigas Athanassios (Ethan) Strigas, PhD, MBA, is a Professor at the University of Peloponnese - Greece, Faculty of Human Movement and Quality of Life in the Department of Sport Management. He taught sport management university courses in the U.S for several years. His research interests focus on sport volunteerism (volunteer motives and volunteer programs' legacy), sport leadership (women in leadership positions in sport), sport ethics \& integrity (the use of AI in detecting game manipulation), and management of sport activities for people with disabilities. His research work on sport volunteerism has received international recognition. Currently, he serves as the Coordinator of Educational Programs for the National Platform of Sport Integrity (E.P.ATHL.A) within the Greek Ministry of Sports.

\section{References}

Bandura, A. (1997). Self-efficacy: The exercise of control. W H Freeman/Times Books/ Henry Holt \& Co.

Bandura, A. (1977). Self-efficacy: toward a unifying theory of behavioral change. Psychological review, 84 (2), 191.

Bar-On, R. (1997). The Emotional Quotient Inventory (EQ-i): A test of emotional intelligence. Toronto, Canada: Multi-Health Systems, Inc. 
Bar-On, R. (2000). Emotional and social intelligence: Insights from the Emotional Quotient Inventory (EQ-i). In R. Bar-On and J. D. A. Parker (Eds.), Handbook of emotional intelligence. San Francisco: Jossey-Bass.

Bar-On, R. (2006). The Bar-On Model of Emotional-Social Intelligence. Psicothema. 18 Suppl. 13-25.

Bar-On, R., Maree, J. G., \& Elias, M. J. (Eds.). (2007). Educating people to be emotionally intelligent. Praeger Publishers/Greenwood Publishing Group.

Brackett, M. A., Rivers, S. E., Shiffman, S., Lerner, N., \& Salovey, P. (2006). Relating emotional abilities to social functioning: A comparison of self-report and performance measures of Emotional Intelligence. Journal of Personality and Social Psychology, 91(4), 780-795.

Berkman L. F., Glass T., Brissette I., Seeman T. E. (2000). From social integration to health: Durkheim in the new millennium. Social Science and Medicine. 2000 Sep; 51 (6):84357. doi: 10.1016/s0277-9536(00)00065-4.

Brotheridge, C. M., \& Grandey, A. A. (2002). Emotional labor and burnout: Comparing two perspectives of "people work". Journal of vocational behavior, 60 (1), 17-39.

Chan, D. W. (2004). Perceived emotional intelligence and self-efficacy among Chinese secondary school teachers in Hong Kong. Personality and Individual Differences 36(8), 1781-1795.

Chan, D. W. (2008). Dimensions of Teacher Self-efficacy among Chinese Secondary School Teachers in Hong Kong. Educational Psychology, 28(2), 181-194

Corcoran, R. P., \& Tormey, R. (2013). Does emotional intelligence predict student teachers' performance? Teaching and Teacher Education, 35, 34-42. https://doi.org/10.1016/j.tate.2013.04.008

Dawson H. \& Scott L. R. (2013). Teaching Students with Disabilities Efficacy Scale: Development and Validation, Inclusion, Vol. 1, No. 3, 181-196

Diamantopoulou, Г., Gouridou, E., \& Platsidou, M. (2015). Emotional Intelligence Skills of the "Good Teacher": Comparing the Evaluations of Teachers, Students and Parents. In Poster presented at the International Convention of Psychological Science. Amsterdam.

De Jong, T. (2005). A framework of principles and best practice for managing student behaviour in the Australian educational context. School Psychology International, 26(3); 353-370

Di Fabio, A., \& Palazzeschi, L. (2008). Emotional intelligence and self-efficacy in a sample of Italian high school teachers. Social Behavior and Personality: An international journal, 36(3), 315-326.

Eminoğlu Küçüktepe, S., Akbağ, M., \& Eminoğlu Özmercan E. (2017). An Investigation Regarding the Preservice Teachers' Emotional Literacy Levels and Self-Efficacy Beliefs, Journal of Education and Learning; Vol. 6, No. 4, doi:10.5539/jel.v6n4p267 Ghanizadeh, A., \& Moafian, F. (2010). The role of EFL teachers emotional intelligence in their success. ELT Journal, 64(4), 424-435.

Gardner, H. (1987). The theory of multiple intelligences. Annals of Dyslexia, p19-35. 
Gardner, H., \& Hatch, T. (1989). Educational implications of the theory of multiple intelligences. Educational researcher, 18(8), 4-10.

Goleman, D. (1995). Emotional intelligence. New York, NY: Bantam Books.

Goleman, D. (1998). Working with emotional intelligence. New York, NY: Bantam

Goleman, D. (2012). Emotional intelligence: Why it can matter more than IQ. Bantam.

Groundwater-Smith, S. (2005). Through the keyhole into the staffroom: Practitioner inquiry into School. AHIGS Conference. Shore School.

Gunter, L., Caldarella, P., Korth, B. \& Young, K. R. (2012). Promoting social and emotional learning in preschool students: A study of Strong Start Pre-K. Early Childhood Education Journal, 40, 151-159.

Gürol, A., Özercan, M. G., Yalçin, H. (2010). A comparative analysis of pre-service teachers' perceptions of self-efficacy and emotional intelligence. Procedia Social and Behavioral Sciences 2, $3246-3251$

Klassen, R. M., \& Chiu, M. M. (2010). Effects on teachers' self-efficacy and job satisfaction: Teacher gender, years of experience, and job stress. Journal of Educational Psychology, 102(3), 741-756. https://doi.org/10.1037/a0019237

Koçoğlu, Z. (2011). Emotional intelligence and teacher efficacy: a study of Turkish EFL preservice teachers. Teacher Development: An international journal of teachers' professional development, 15:4, $471-484$.

Küçüktepe, S. E., Akbag, M., \& Özmercan, E. E. (2017). An Investigation Regarding the Preservice Teachers' Emotional Literacy Levels and Self-Efficacy Beliefs. Journal of Education and Learning, 6(4), 267-275.

Matthews, G., Emo, A. K., Roberts, R. D., \& Zeidner, M. (2006). What Is This Thing Called Emotional Intelligence? In K. R. Murphy (Ed.), A critique of emotional intelligence: What are the problems and how can they be fixed? (pp. 3-36). Lawrence Erlbaum Associates Publishers.

Mayer, J. D. (2002). MSCEIT: Mayer-Salovey-Caruso emotional intelligence test. Toronto, Canada: Multi-Health Systems.

Mayer, J. D., Caruso, D., \& Salovey, P. (1999). Emotional intelligence meets traditional standards for an intelligence. Intelligence, 27, 267-298. doi.org/10.1016/S01602896(99)00016-1

Mayer, J. D., \& Salovey, P. (1997). What is emotional intelligence? In P. Salovey \& D. J. Sluyter (Eds.), Emotional development and emotional intelligence: Educational implications (pp. 3-34). Basic Books.

Mayer, J. D., Salovey, P., \& Caruso, D. R. (2008). Emotional intelligence: New ability or eclectic traits? American Psychologist, 63(6), 503-517. https://doi.org/10.1037/0003066X.63.6.503

Nikoopour, J., Farsani, M. A., Tajbakhsh, M., \& Sadat Kiyaie, S. H. (2012). The Relationship between Trait Emotional Intelligence and Self-efficacy among Iranian EFL Teachers. Journal of Language Teaching \& Research, 3(6). 
Penrose, A., Perry, C., \& Bell, I. (2007). Emotional intelligence and teacher self-efficacy: The contribution of teacher status and length of experience, in Issues in Educational Research, 17(1): 107-126.

Platsidou, M., \& Mastorodimou, E. (2009). Emotional and moral dimensions of students' perceptions of the "excellent teacher". 12th International Conference on Inclusive Education in the Balkan Countries: Policy and Practice. Ohrid.

Poulou V. (2017). An examination of the relationship among teachers' perceptions of social-emotional learning, teaching efficacy, teacher-student interactions, and students' behavioral difficulties, International Journal of School \& Educational Psychology, 5:2, 126-136, DOI: 10.1080/21683603.2016.1203851

Perry, C., \& Ball, I. (2008). Identifying the underlying dimensions of teachers' emotional intelligence. Problems of education in the 21st Century. Peculiarities of contemporary education, 7, 89-98.

Rastegar, M., \& Memarpour, S. (2009). The relationship between emotional intelligence and self-efficacy among Iranian EFL teachers. System, 37, 700 -707.

Roffey, S. (2008). Emotional literacy and the ecology of school wellbeing. Educational and Child Psychology, 25(2), 29-39.

Sabina Valente, Augusta Veiga-Branco, Hugo Rebello, Abílio Afonso Lourenco, Ana Maria Cristóvão (2020). The Relationship between Emotional Intelligence Ability and Teacher Efficacy. Universal Journal of Educational Research, 8(3), 916 - 923. DOI: 10.13189/ujer.2020.080324.

Salovey, P., \& Mayer, J. D. (1990). Emotional intelligence. Imagination, cognition and personality, 9(3), 185-211

Schutte, N. S., Malouff, J. M., Hall, L. E., Haggerty, D. J., Cooper, J. T., Golden, C. J., \& Dornheim, L. (1998). Development and validation of a measure of emotional intelligence. Personality and individual differences, 25(2), 167-177

Tschannen-Moran, M., \& Woolfolk Hoy, A. (2001). Teacher efficacy: Capturing an elusive construct. Teaching and Teacher Education, 17, 783-805.

Valente, Augusta Veiga-Branco, Hugo Rebelo, Abílio Afonso Lourenço, Ana Maria Cristóvão (2020). The Relationship between Emotional Intelligence Ability and Teacher Efficacy. Universal Journal of Educational Research, 8(3), 916 - 923. DOI: 10.13189/ujer.2020.080324

White A., Kerim M, 2001 The social and cultural impact of Short-Term Study-Abroad Strategies, 3rd edn. Chicago, IL, USA, pp 3430-3457

Yin, H. B., Lee, J. C. K., Jin, Y. L., \& Zhang, Z. H. (2013). The effect of trust on teacher empowerment: the mediation of teacher efficacy. Educational Studies, 39(1), 13-28. 
Konstantina Katsora, Stylianos Kaprinis, Athanasios Strigas

Creative Commons licensing terms

Authors will retain the copyright of their published articles agreeing that a Creative Commons Attribution 4.0 International License (CC BY 4.0) terms will be applied to their work. Under the terms of this license, no permission is required from the author(s) or publisher for members of the community to copy, distribute, transmit or adapt the article content, providing a proper, prominent and unambiguous attribution to the authors in a manner that makes clear that the materials are being reused under permission of a Creative Commons License. Views, opinions and conclusions expressed in this research article are views, opinions and conclusions of the author(s). Open Access Publishing Group and European Journal of Special Education Research shall not be responsible or answerable for any loss, damage or liability caused in relation to/arising out of conflict of interests, copyright violations and inappropriate or inaccurate use of any kind content related or integrated on the research work. All the published works are meeting the Open Access Publishing requirements and can be freely accessed, shared, modified, distributed and used in educational, commercial and non-commercial purposes under a Creative Commons Attribution 4.0 International License (CC BY 4.0). 